\title{
LEPROSY IN BENIN AND WARRI PROVINCES OF NIGERIA.*
}

I. I ANGAUER.

In order to start propaganda, survey, treatment, in I938 we announced that free treatment would be given to lepers who could not or would not be admitted to the settlement. The reaction was very curious. The chief of the nearest village brought me many patients, but not one leper! He was disappointed when I refused to treat them. He said there are some lepers around and he will let them know, but he would rather prefer that I opened a dispensary for all other diseases. In his opinion it was much more important. Then some lepers arrived, they were chiefly lepers from very far who were seeking admission to Ossiomo Leper Settlement and being disappointed, established themselves around the settlement along with some lepers dismissed from Ossiomo Leper Settlement for stealing, fighting, etc. Having no definite means of existence, being strangers in the area, they did not despise any means of earning money. For instance, women were prostitutes for lepers of the settlement. Ossiomo Settlement is surrounded in the vicinity of 5 miles chiefly by camps of strangers from all parts of the province, and even from other provinces, having their own excellent reasons for staying there. There are no real native villages nearby, which makes our outside work very difficult.

However, 82 lepers were registered to attend outside treatment, I.T. were admitted to Ossiomo Settlement; Io stopped coming after a few injections, three died, the others continued to come more or less regularly. Two only showed definite signs of improvement. The majority of these lepers coming for treatment needed chiefly food. I visited some of the huts where people were living. They were appalling. From the survey point of view the results were nil, because these lepers were chiefly strangers in the area. From the propaganda view there was no improvement, therefore the lepers and the healthy population could not see any advantage in the treatment. And as regards the treatment, without regular observation, without improving their health and giving decent food and lodging, in my opinion it was even harmful. Some of the patients were getting definitely worse.

Amongst all of them there were only two lepromatous (contagious) cases. Because of the reasons mentioned above, and as

* This is part of a report by the doctor in charge of the Ossiomo Settlement, Benin Prorince. A description of this settlement appears on page 62 of the last number of Leprosy Reviez. 
some unpleasantness in the settlement, such as repeated burglaries, led to the suspicion of these outside patients, and as the healthy population around began to complain that too many lepers had established themselves around and were troublesome in the area, I decided to stop the out-patient clinic at Ossiomo and to establish it in some normal village where chiefs would be willing to cooperate. I proposed to one village in Agbor District, where I knew the incidence of leprosy was very high, to discuss what could be done for lepers. When I arrived there heavy rain started, which naturally prevented lepers coming. I asked the chiefs about the population of the village based on the tax-paying members, because they could not tell it otherwise. Out of a total of 600 inhabitants, 60 lepers arrived; out of these II were of the $\mathrm{L}_{3}$ type (contagious). The chiefs declared that they were much more numerous, but the rain prevented them coming, and also they were afraid.

Then, for the first time, I heard the following story about the first year of the Ossiomo Leper Settlement. In I93I the general population and the lepers were convinced that inside the settlement was a big hole into which lepers were pushed and buried alive. This explains why at the beginning very miserable or ready-foranything lepers arrived at Ossiomo Settlement. Now the settlement has won their confidence, but any attempt to count lepers still arouses suspicion, and outside free treatment is considered a trap. However, I had a talk with the 60 lepers who were present. and all of them said they would be willing to build a separate compound if they received injections; they asked nothing more. As for the chiefs, they put immediately the question of finance: "If Doctor comes, she will need a shed; who will pay for it?" "If Doctor comes, she will need a man to help her, it must be a man of our village and of course he must be paid."

I asked if familial segregation was practised, and they said it was in the old time, but now lepers are too numerous and too " bold" and resent strict measures which (being perhaps rather barbarous) might meet also the disapproval of " white men." It confirmed my own information and the statements of several District Officers of our provinces. I refused to discuss any financial problems with them, mentioning that I was willing to undertake treatment gratis, but that would be all I could promise them. I proposed also to train a boy of the village to do propaganda work against leprosy, and the chiefs sent me a boy who is now finishing his training with me. He received from me courses on leprosy. first-aid, general hygiene concerning villages, habitation, tropical diseases and their prophylaxis. I was going to start injections in this village, but, unfortunately, the officer in charge of the 
medical stores informed me that it was not advisable to ask for extra supplies of hydnocarpus oil as there might be a shortage of supplies due to war conditions.

I decided then to start anti-leprosy propaganda through education of the people. I noticed before that my lepers themselves are the best propagandists, and I particularly insisted in the settlement on their having the right ideas about leprosy. Usually each of the inmates goes on leave for two weeks every year, and their obvious improvement, cleanliness and confidence in treatment make an impression on the population. Very often lepers returning from home bring one or two lepers for admission to the settlement. They have begun to understand that early cases are rather easier to cure, that the lepromatous type is contagious, that children are particularly sensitive to leprosy, that good food and cleanliness are important in the treatment of leprosy, and they carry these ideas to their villages. Very often they bring me people to examine to be sure whether it is leprosy. Natives of this area have poor general health, due probably to deficiency of food and the general unhygienic conditions of life. Many villages in Warri Province are surrounded by swamps and this dampness is certainly favourable to the increase of leprosy. The peculiar mentality of the natives of this area contributes to the progress of leprosy. They marry lepers, they don't insist on isolation, and don't seem to be anxious for treatment. There is also a lot of inertia. They are glad if something is done for them, but they don't want to make any effort themselves, and if they let themselves be persuaded at the moment, their enthusiasm fades away very quickly. Moreover, there is much superstition; for example, some of the chiefs declare that they are able to cure leprosy themselves and see in Ossiomo Settlement a rival! I have a very curious letter about this. Nevertheless, very slowly we are succeeding in introducing right ideas on leprosy into the people. It is also through our patients of Benin Division that we could bring the right kind of patients to out-patient clincs which we re-opened in October, I939, at Ossiomo Settlement.

Eighteen patients are now attending regularly this clinic, but I refuse treatment to those from outside the area and to lepers whose general health is very deficient (there were five in number). I advised them to improve their health by good food, exercise and cleanliness, promising to put them on the list of out-patients if I see any improvement. Several of these out-patients belong to the families of our inmates from Benin Division. It is curious to observe that from the same family we treat sometimes three or four persons, and they are not vague " brothers," but close 
relations. Now and then out-patients receive some drugs and dressings which we succeeded in collecting at home, because Ossiomo funds cannot afford to contribute anything for the outpatient's clinic. Due to paucity of the population and the mentality of natives, the number of these patients is not big (though increasing). Not one of them is of $\mathrm{L}$. type. But the number of patients asking for admission to Ossiomo Settlement is increasing, and there are days when we refuse admission to three to five lepers, and they continue to knock at the door.

Out of the total patients at Ossiomo, 62 are paying patients. They pay for their maintenance at Ossiomo Leper Settlement, drugs and clothing included, and contribute towards administrative expenses by their work. They pay $£^{2} 6 \mathrm{6s}$. od. per year. Their number is growing. I regret that so many patients are admitted to the Settlement with Paupers' Certificates, when they positively could pay this amount. I consulted this year several District Officers on this subject, but they were all rather pessimistic. Families " would not like" to pay for the lepers. I expect we will be able to accommodate 500 patients without asking for extra funds if all new admissions are of the paying-patients category. But we must not forget that our aim is not to segregate in the Settlement a few hundred from thousands of lepers in our provinces. Our problem is how to stamp out leprosy in our provinces.

The Enugu Leprosy Conference expressed the wish that this work should be carried on on the basis of propaganda-surveytreatment method. Those who know the conditions of life in the Provinces of Benin and Warri know their special difficulties. We must not, therefore, copy slavishly the methods of other provinces, but adopt plans, as recommended at the Enugu Conference, according to the conditions of our provinces, making of Ossiomo Leper Settlement a big inter-provincial centre of the anti-leprosy campaign, as is done in the other provinces. 